\title{
Aromatic Constituents from the Heartwood of Santalum album L.
}

\author{
Tae Hoon Kim, ${ }^{a}$ Hideyuki Ito, ${ }^{*, a}$ Kikuyo Hayashi, ${ }^{b}$ Toshio Hasegawa,,${ }^{b}$ Takahisa Machiguchi, ${ }^{b}$ and \\ Takashi YoshidA ${ }^{a}$ \\ ${ }^{a}$ Faculty of Pharmaceutical Sciences, Okayama University; Tsushima, Okayama 700-8530, Japan: and ${ }^{b}$ Faculty of \\ Science, Saitama University; Sakuraku, Saitama 338-8570, Japan. \\ Received February 2, 2005; accepted March 14, 2005; published online March 18, 2005
}

\begin{abstract}
A phytochemical investigation of the polar constituents in the heartwood of Indian Santalum album L. resulted in the isolation of three new neolignans (1-3) and a new aromatic ester (4), along with 14 known components. The structures of the new compounds $(1-4)$ were established using spectroscopic methods.
\end{abstract}

Key words Santalum album; Santalaceae; sandalwood; benzodioxane; dihydrobenzo[b]furan; 8.O.4'-type neolignan

Santalum album LinN. (Santalaceae) is a mid-sized evergreen parasitic tree widely distributed in India, Malaysia, and Australia; it is commonly known as sandalwood. The essential oil of sandalwood is usually prepared by steam distillation from chips and billets cut from the heartwood and is used in perfumes, cosmetics, and sacred unguents. ${ }^{1)}$ Sandalwood oil has various biological activities, such as antiviral and chemopreventive effects. ${ }^{2-5)}$ Previous phytochemical studies of $S$. album revealed triterpenoids, 6,7) phenylpropanoids, ${ }^{8)}$ and sesquiterpenoids, ${ }^{9-12)}$ represented by $\alpha$ and $\beta$-santalol. ${ }^{13,14)}$ Recent investigations found that the major sesquiterpene, $\alpha$-santalol, was responsible for the pharmacological effects of sandalwood oil. ${ }^{15-19)}$ As part of our continuing search for novel bioactive natural products, we investigated an ethyl acetate extract of heartwood chips of East Indian (Mysore) S. album L. and isolated four new compounds (1-4, Fig. 1), together with 14 known metabolites. Here, we describe the structure elucidation of these new compounds.

\section{Results and Discussion}

Successive column and preparative layer chromatographic purification of the ethyl acetate-soluble fraction of the methanolic extract of $S$. album led to the isolation and characterization of three new neolignans $(\mathbf{1}-\mathbf{3})$ and a new benzoic acid derivative (4), along with 14 known constituents. The known compounds were identified as 7,8-erythro- and 7,8-threo-4,9,9' -trihydroxy-3,3' -dimethoxy-8.O.4' -neolignans $(\mathbf{5}, \mathbf{6}),{ }^{20)}$ dihydrodehydrodiconiferyl alcohol $(7),{ }^{21)}$ (7S,8S)-3-methoxy-3',7-epoxy-8, $4^{\prime}$-oxyneoligna-4,9,9' -triol

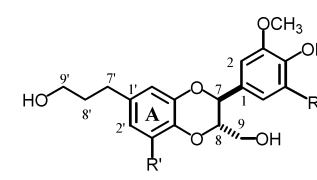

$1: \mathrm{R}=\mathrm{OH}, \Delta^{7^{\prime}\left(8^{\prime}\right)}, \mathrm{R}^{\prime}=\mathrm{OCH}_{3}$

$1 \mathrm{a}: \mathrm{R}=\mathrm{OH}, \mathrm{R}^{\prime}=\mathrm{OCH}_{3}$

$2: \mathrm{R}=\mathrm{OCH}_{3}, \Delta^{7^{\prime}\left(8^{\prime}\right)}, \mathrm{R}^{\prime}=\mathrm{OCH}_{3}$

2a $: \mathrm{R}=\mathrm{R}^{\prime}=\mathrm{OCH}_{3}$

$8 \cdot R=R^{\prime}=H$

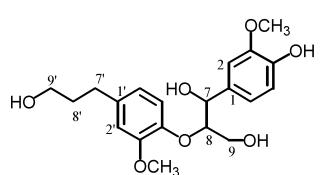

$5:$ : 7,8-erythro

$6: 7,8$-threo

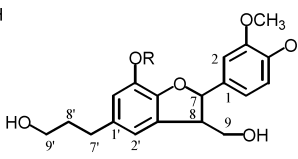

$3:(7 S, 8 R) \mathrm{R}=\mathrm{H}$

$7:(7 R, 8 S) \mathrm{R}=\mathrm{CH}_{3}$

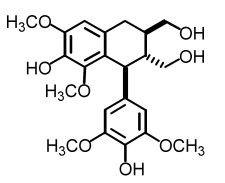

9

Fig. 1

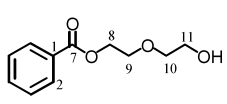

4

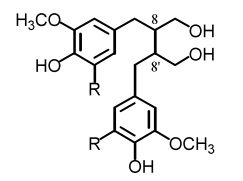

$10:\left(8 S, 8^{\prime} S\right) \mathrm{R}=\mathrm{OCH}_{3}$ $11:\left(8 R, 8^{\prime} R\right) \mathrm{R}=\mathrm{H}$
(8) ${ }^{22)} \quad\left(7^{\prime} S, 8 R, 8^{\prime} R\right)$-lyoniresinol (9), ${ }^{23)}$ 2,3-bis[(4-hydroxy3,5-dimethoxyphenyl)-methyl]-1,4-butanediol (10), ${ }^{24)}(-)$ secoisolariciresinol (11), ${ }^{25)} \omega$-hydroxypropioguaiacone, ${ }^{26)} 3$ hydroxy-1-(4-hydroxy-3,5-dimethoxyphenyl)-1-propanone, ${ }^{27)} C$-veratroylglycol, ${ }^{28)}$ syringic acid, vanillic acid, isovanillic acid, and vanillic acid 4- $O$-neohesperidoside ${ }^{29)}$ from comparisons of their physicochemical and spectroscopic data $\left({ }^{1} \mathrm{H}-,{ }^{13} \mathrm{C}-\mathrm{NMR}, 2 \mathrm{D} \mathrm{NMR}\right.$, and MS) with those of authentic samples and reference data. These polar phenolic constituents were first isolated from $S$. album heartwood.

Compound 1 was obtained as a colorless oil, $[\alpha]_{\mathrm{D}}^{20}+8.0^{\circ}$ $(\mathrm{MeOH})$. Its molecular formula was determined to be $\mathrm{C}_{20} \mathrm{H}_{22} \mathrm{O}_{8}$ using positive high-resolution (HR) fast atom bombardment (FAB)-MS, which showed a pseudomolecular ion peak at $\mathrm{m} / z$ 391.1379 $[\mathrm{M}+\mathrm{H}]^{+}$. The ${ }^{1} \mathrm{H}-\mathrm{NMR}$ spectrum of $\mathbf{1}$ (Table 1) in $\mathrm{CD}_{3} \mathrm{OD}$ showed two sets of meta-coupled signals at $\delta_{\mathrm{H}} 6.73\left(1 \mathrm{H}, \mathrm{d}, J=1.8 \mathrm{~Hz}, \mathrm{H}-2^{\prime}\right) / 6.67(1 \mathrm{H}, \mathrm{d}, J=1.8 \mathrm{~Hz}, \mathrm{H}-$ $\left.6^{\prime}\right)$ and $6.62(1 \mathrm{H}, \mathrm{d}, J=1.8 \mathrm{~Hz}, \mathrm{H}-2) / 6.60(1 \mathrm{H}, \mathrm{d}, J=1.8 \mathrm{~Hz}$, $\mathrm{H}-6)$, indicating the presence of two 1,3,4,5-tetrasubstituted aromatic rings. The spectrum also included signals attributable to trans olefinic protons $\left[\delta_{\mathrm{H}} 6.52(1 \mathrm{H}\right.$, brd, $J=16.2 \mathrm{~Hz}$, $\left.\mathrm{H}-7^{\prime}\right)$ and $\left.6.27\left(1 \mathrm{H}, \mathrm{dt}, J=16.2,5.4 \mathrm{~Hz}, \mathrm{H}-8^{\prime}\right)\right]$, a hydroxymethyl proton $\left[\delta_{\mathrm{H}} 4.24\left(2 \mathrm{H}, \mathrm{dd}, J=5.4,1.8 \mathrm{~Hz}, \mathrm{H}-9^{\prime}\right)\right]$, and two methoxyl groups $\left[\delta_{\mathrm{H}} 3.92(3 \mathrm{H}, \mathrm{s})\right.$ and $\left.3.89(3 \mathrm{H}, \mathrm{s})\right]$. In addition to these proton signals, the ${ }^{1} \mathrm{H}-{ }^{1} \mathrm{H}$ correlated spectroscopy (COSY) spectrum of 1 revealed aliphatic AMXYtype signals $\left[\delta_{\mathrm{H}} 4.84(1 \mathrm{H}, \mathrm{d}, J=8.4 \mathrm{~Hz}, \mathrm{H}-7), 4.03(1 \mathrm{H}\right.$, ddd, $J=8.4,4.8,3.0 \mathrm{~Hz}, \mathrm{H}-8), 3.76$ (1H, dd, $J=12.6,3.0 \mathrm{~Hz}, \mathrm{H}-9)$, and $3.56(1 \mathrm{H}, \mathrm{dd}, J=12.6,4.8 \mathrm{~Hz}, \mathrm{H}-9)]$. The deshielded benzylic oxymethine proton at $\delta_{\mathrm{H}} 4.84(\mathrm{H}-7)$ and the doublet of double doublets at $\delta_{\mathrm{H}} 4.03(\mathrm{H}-8)$ implied the linkage of two phenylpropanoid units via a 1,4-dioxane bridge. ${ }^{30,31)} \mathrm{Re}$ cently, several studies have demonstrated that the location of the side chain on the A-ring $\left(\mathrm{C}-1^{\prime}\right.$ or $\left.\mathrm{C}-2^{\prime}\right)$ of benzodioxanetype neolignans is difficult to determine using heteronuclear multiple bond connectivity (HMBC). ${ }^{31,32)}$ In order to overcome this problem, NMR measurement techniques, such as long-range selective proton decoupling (LSPD), and a selective insensitive nuclei enhanced using a polarization transfer (INEPT) technique had to be applied to elucidate the structure of the neolignans and a flavonolignan. ${ }^{30,31,33)}$ The linkage point of the substituent on the 1,4-dioxane moiety in $\mathbf{1}$ was determined unambiguously from $\mathrm{HMBC}$ and nuclear Overhauser and exchange spectroscopy (NOESY) spectra using pyridine- $d_{5}$ as the solvent, which gave clear correlations of the $\mathrm{H}-7 / \mathrm{C}-5^{\prime}$ and $\mathrm{H}-2^{\prime}, 9 / \mathrm{C}-4^{\prime}$ (Fig. 2). In addition, long- 
Table 1. NMR Data for Compound 1

\begin{tabular}{|c|c|c|c|c|c|c|}
\hline Position & $\delta_{\mathrm{H}}^{a)}$ (mult., $J \mathrm{~Hz}$ ) & $\delta_{\mathrm{H}}^{b)}$ (mult., $J \mathrm{~Hz}$ ) & $\delta_{\mathrm{C}}^{a)}$ & $\delta_{\mathrm{C}}^{b)}$ & HMBC correlations & NOESY \\
\hline 1 & & & 128.6 & 128.1 & & \\
\hline 2 & $6.62(\mathrm{~d}, 1.8)$ & $7.00(\mathrm{~d}, 1.8)$ & 104.0 & 103.7 & $\mathrm{C}-1,{ }^{a)} 3,{ }^{c)} 4,{ }^{b)} 6,{ }^{c)} 7^{c)}$ & $\left.\mathrm{H}-3^{c)}\left(\mathrm{OCH}_{3}\right), 7,{ }^{c)} 8^{c}\right)$ \\
\hline 3 & & & 149.8 & 149.5 & & \\
\hline 4 & & & 135.9 & 136.6 & & \\
\hline 5 & & & 146.8 & 148.0 & & \\
\hline 6 & $6.60(\mathrm{~d}, 1.8)$ & $7.36(\mathrm{~d}, 1.8)$ & 109.3 & 111.1 & $\mathrm{C}-2,,^{c)} 4,,^{c)} 5,^{c)} 7^{c)}$ & $\mathrm{H}-7,{ }^{b)} 8^{b)}$ \\
\hline 7 & $4.84(\mathrm{~d}, 8.4)$ & $5.44(\mathrm{~d}, 7.8)$ & 77.7 & 77.3 & $\mathrm{C}-1,{ }^{c)} 2,{ }^{c)} 6,{ }^{c)} 8,{ }^{c)} 5^{(b)}$ & $\mathrm{H}-2,{ }^{c)} 6,{ }^{b)} 8,{ }^{c)} 9^{c)}$ \\
\hline 8 & 4.03 (ddd, 8.4, 4.8, 3.0) & $4.35(\mathrm{~m})$ & 80.1 & 80.0 & $\mathrm{C}-7^{c)}$ & $\mathrm{H}-2,{ }^{c)} 6,{ }^{b)} 7,{ }^{c)} 9^{c)}$ \\
\hline \multirow[t]{2}{*}{9} & $3.76(\mathrm{dd}, 12.6,3.0)$ & $4.23(\mathrm{dd}, 12.6,2.4)$ & 62.1 & 61.5 & $\mathrm{C}-7^{(c)} 8^{b)}$ & $\mathrm{H}-7,{ }^{c)} 8,{ }^{a)} 9^{c)}$ \\
\hline & $3.56(\mathrm{dd}, 12.6,4.8)$ & $3.95(\mathrm{dd}, 12.6,3.6)$ & & & $\mathrm{C}-4^{\prime},{ }^{b)} 7^{c)}$ & $\left.\mathrm{H}-7,{ }^{c}\right) 8,{ }^{a)} 9^{c)}$ \\
\hline $1^{\prime}$ & & & 134.2 & 129.6 & & \\
\hline $2^{\prime}$ & $6.73(\mathrm{~d}, 1.8)$ & $6.87(\mathrm{~d}, 1.8)$ & 103.9 & 103.5 & $\mathrm{C}-1^{\prime},{ }^{c)} 3^{\prime},{ }^{c)} 4^{\prime},{ }^{b)} 5^{\prime},{ }^{a)} 6^{(a)}$ & $\mathrm{H}-3^{\prime c)}\left(\mathrm{OCH}_{3}\right), 8^{\prime c)}$ \\
\hline $3^{\prime}$ & & & 150.2 & 150.0 & & \\
\hline $4^{\prime}$ & & & 131.1 & 134.1 & & \\
\hline $5^{\prime}$ & & & 145.8 & 145.5 & & \\
\hline $6^{\prime}$ & $6.67(\mathrm{~d}, 1.8)$ & $7.03(\mathrm{~d}, 1.8)$ & 109.2 & 108.6 & $\mathrm{C}-1^{\prime},{ }^{c)} 2^{\prime},{ }^{c)} 4^{\prime},{ }^{b)} 5^{\prime},{ }^{b)} 7^{(a)}$ & $\mathrm{H}-7^{\prime c)}$ \\
\hline $7^{\prime}$ & $6.52(\mathrm{brd}, 16.2)$ & $6.88(\mathrm{brd}, 15.6)$ & 131.6 & 130.3 & $\mathrm{C}-2^{\prime},{ }^{c)} 6^{\prime},{ }^{a)} 9^{\prime c)}$ & $\mathrm{H}-2^{\prime},{ }^{a)} 6^{\prime},{ }^{c)} 9^{\prime c)}$ \\
\hline $8^{\prime}$ & $6.27(\mathrm{dt}, 16.2,5.4)$ & $6.62(\mathrm{dt}, 15.6,5.4)$ & 128.5 & 129.9 & $\mathrm{C}-7^{\prime},{ }^{c)} 9^{(c)}$ & $\mathrm{H}-2^{\prime},{ }^{c)} 6^{\prime},{ }^{a)} 9^{\prime c)}$ \\
\hline $9^{\prime}$ & $4.24(\mathrm{dd}, 5.4,1.8)$ & $4.57(\mathrm{dd}, 5.4,1.8)$ & 63.7 & 63.1 & $\mathrm{C}-7^{\prime},{ }^{a)} 8^{\prime c)}$ & $\mathrm{H}-7^{\prime},^{c)} 8^{\prime c)}$ \\
\hline $\mathrm{OCH}_{3}-3$ & $3.89(\mathrm{~s})$ & $3.76(\mathrm{~s})$ & 56.7 & 56 & $\mathrm{C}-3^{\prime c)}$ & $\mathrm{H}-2^{\prime c)}$ \\
\hline $\mathrm{OCH}_{3}-3^{\prime}$ & $3.92(\mathrm{~s})$ & $3.82(\mathrm{~s})$ & 56.7 & 55.9 & $\mathrm{C}-3^{c)}$ & $\mathrm{H}-2^{c)}$ \\
\hline
\end{tabular}

a) Observed in $\mathrm{CD}_{3} \mathrm{OD}$. b) Observed in $\mathrm{C}_{5} \mathrm{D}_{5} \mathrm{~N}$. c) Observed in both $\mathrm{CD}_{3} \mathrm{OD}$ and $\mathrm{C}_{5} \mathrm{D}_{5} \mathrm{~N}$.

range correlations between each of the two methoxyl signals $\left(\delta_{\mathrm{H}} 3.92,3.89\right)$ and aromatic carbons at $\delta_{\mathrm{C}} 150.2$ and 149.8 , respectively, indicated the position of the methoxyl groups at $\mathrm{C}-3$ and $\mathrm{C}-3^{\prime}$. The coupling constant $\left(J_{7,8}=8.4 \mathrm{~Hz}\right)$ between $\mathrm{H}-7$ and $\mathrm{H}-8$, and the NOE correlations between $\mathrm{H}-8 / \mathrm{H}-6$ and $\mathrm{H}-7 / \mathrm{H}-9$ clearly indicated a threo configuration of the chiral centers on the dioxane ring. ${ }^{34,35)}$ The absolute configurations at $\mathrm{C}-7$ and $\mathrm{C}-8$ were determined by the circular dichroism (CD) spectral comparison with the analogous neolignans, eusiderins, whose absolute configurations were determined based on the $\mathrm{CD}$ comparison with synthetic analogs $s^{36)}$ as follows. To remove a contribution of a double bond conjugated with the A-ring in 1, a dihydro-derivative 1a which has similar chromophoric system to those of the reference compounds was prepared by catalytic hydrogenation over $\mathrm{PtO}_{2}$. The observed CD spectrum of $1 \mathbf{a}\left([\theta]_{226}-1800\right.$, $\left.[\theta]_{238}+4806,[\theta]_{299}-1010\right)$ allowed the assignment of $7 S, 8 S$ configurations. $^{36)}$ Consequently, compound $\mathbf{1}$ was represented by structure 1 .

Compound 2 was isolated as a colorless oil, $[\alpha]_{\mathrm{D}}^{20}-16.0^{\circ}$ $(\mathrm{MeOH})$. The electrospray ionization (ESI)-MS of 2 showed a pseudomolecular ion peak at $m / z 422\left[\mathrm{M}+\mathrm{NH}_{4}\right]^{+}$, which was 14 mass units larger than $\mathbf{1}$, and its molecular formula, $\mathrm{C}_{21} \mathrm{H}_{24} \mathrm{O}_{8}$, was confirmed using HR-ESI-MS. The ${ }^{1} \mathrm{H}$ - and ${ }^{13} \mathrm{C}$-NMR spectra of $\mathbf{2}$ were very similar to those of $\mathbf{1}$, except for the presence of an extra methoxyl signal $\left[\delta_{\mathrm{H}} 3.90(3 \mathrm{H}, \mathrm{s})\right.$, $\left.\delta_{\mathrm{C}} 54.1\right]$ and a magnetically equivalent $2 \mathrm{H}$-singlet $\left(\delta_{\mathrm{H}} 6.78\right)$ instead of the two meta-coupled aromatic signals in 1. Compound $\mathbf{2}$ was regarded as the $5-O$-methyl congener of $\mathbf{1}$. The $7 S, 8 S$-configuration of $\mathbf{2}$ was also evidenced by the similar CD spectrum of its dihydro-derivative $\mathbf{2 a}$ to that of $\mathbf{1 a}$. Although the racemic mixture of $\mathbf{2}$ (nitidanin) was reported as a constituent from the bark of Xanthoxylum nitidum, ${ }^{30)}$ this is the first isolation of the $7 S, 8 S$ enatiomer from a natural source.

Compound 3 was obtained as a yellowish oil, $[\alpha]_{\mathrm{D}}^{20}-5.3^{\circ}$ $(\mathrm{MeOH})$. The HR-ESI-MS of $\mathbf{3}$ had a molecular ion peak at $m / z 364.1778\left[\mathrm{M}+\mathrm{NH}_{4}\right]^{+}$, consistent with the molecular for-

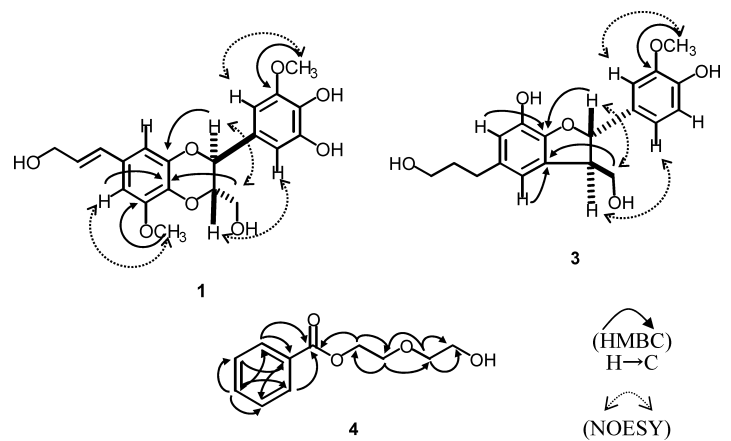

Fig. 2. HMBC and NOESY Correlations for Compounds $\mathbf{1}, \mathbf{3}$ and $\mathbf{4}$

mula $\mathrm{C}_{19} \mathrm{H}_{22} \mathrm{O}_{6}$. The 1D ${ }^{1} \mathrm{H}-\mathrm{NMR}$ and ${ }^{1} \mathrm{H}-{ }^{1} \mathrm{H}$ COSY spectra of 3 indicated the presence of five aromatic protons $\left[\delta_{\mathrm{H}} 7.02\right.$ $(1 \mathrm{H}, \mathrm{d}, J=2.4 \mathrm{~Hz}, \mathrm{H}-2), 6.89(1 \mathrm{H}, \mathrm{d}, J=8.4,2.4 \mathrm{~Hz}, \mathrm{H}-6)$, $6.80(1 \mathrm{H}, \mathrm{d}, J=8.4 \mathrm{~Hz}, \mathrm{H}-5), 6.65\left(1 \mathrm{H}, \mathrm{br}, \mathrm{H}-2^{\prime}\right)$, and 6.61 $\left(1 \mathrm{H}\right.$, br d, $\left.\left.J=1.8 \mathrm{~Hz}, \mathrm{H}-6^{\prime}\right)\right]$, a hydroxypropyl group $\left[\delta_{\mathrm{H}} 3.60\right.$ $\left(2 \mathrm{H}, \mathrm{t}, J=6.0 \mathrm{~Hz}, \mathrm{H}-9^{\prime}\right), 2.60\left(2 \mathrm{H}, \mathrm{brt}, J=7.2 \mathrm{~Hz}, \mathrm{H}-7^{\prime}\right)$, and $\left.1.83\left(2 \mathrm{H}, \mathrm{m}, \mathrm{H}-8^{\prime}\right)\right]$, two methines $\left[\delta_{\mathrm{H}} 5.53(1 \mathrm{H}, \mathrm{d}\right.$, $J=6.0 \mathrm{~Hz}, \mathrm{H}-7), 3.49$ (1H, dd, $J=12.6,6.0 \mathrm{~Hz}, \mathrm{H}-8)]$, a hydroxymethyl $\left[\delta_{\mathrm{H}} 3.87(1 \mathrm{H}, \mathrm{m}, \mathrm{H}-9)\right.$, and $3.79(1 \mathrm{H}$, dd, $J=10.8,7.2 \mathrm{~Hz}, \mathrm{H}-9)]$, and a methoxyl group $\left[\delta_{\mathrm{H}} 3.86(3 \mathrm{H}\right.$, s)]. In addition to the methoxyl carbon signal, 18 skeletal carbon resonances appeared in the ${ }^{13} \mathrm{C}$-NMR spectrum. These spectral features indicated that $\mathbf{3}$ was a dihydro[b]benzofuran-type neolignan formed by two phenylpropanoid units. $^{37)}$ The methoxyl group was located at $\mathrm{C}-3$, based on the HMBC and NOESY ( $\left.\delta_{\mathrm{H}} 3.86 / \mathrm{H}-2\right)$ correlations (Fig. 2). The threo relationship between $\mathrm{H}-7$ and $\mathrm{H}-8$ was inferred from their coupling constant $\left(J_{7,8}=6 \mathrm{~Hz}\right)$, which is similar to that reported in the analogs based on X-ray analysis. ${ }^{38,39}$ ) This arrangement was verified by the NOE correlations between $\mathrm{H}-7$ and $\mathrm{H}-9$ and between $\mathrm{H}-8$ and H-2, 6 (Fig. 2). The absolute structures of many dihydrobenzo[b]furan-type neolignans have been assigned ${ }^{21,40-43)}$ on the basis of the CD results of Achenbach et al. ${ }^{44)}$ However, Antus et al. ${ }^{45)}$ re- 

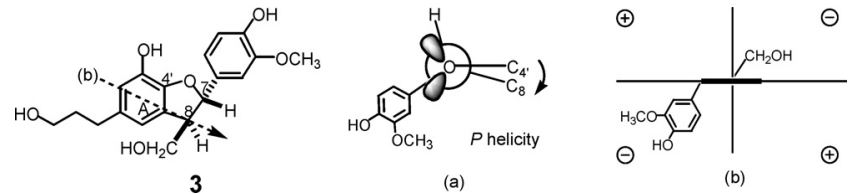

Fig. 3. Projection for ${ }^{1} \mathrm{~L}_{b}$ (a) and ${ }^{1} \mathrm{~L}_{\mathrm{a}}$ (b: Projection in the Direction of Arrow, Wedge Represents the Plane of the A-Ring) Transitions

cently claimed that several published configurational assignments for those neolignans are incorrect and should be revised based on the correlation between $P / M$ helicity of the $O$ heterocyclic ring in chiral 7,8-dihydrobenzo[b]furan and their ${ }^{1} \mathrm{~L}_{\mathrm{b}}$ band $(270-300 \mathrm{~nm}) \mathrm{CD}$ data. This helicity rule is controlled by the presence of oxygen function at C-5', which leads to the positive sign of the ${ }^{1} \mathrm{~L}_{\mathrm{b}}$ band $\mathrm{CD}$ for the predicted $P$ helicity, while the negative sign for the $M$ helicity. Examined data for many natural neolignans confirmed the validity of this helicity rule. ${ }^{45)}$ The CD spectrum of $\mathbf{3}$ showed a positive Cotton effect at $295 \mathrm{~nm}([\theta]+643)$, indicating that the absolute configuration of $\mathbf{3}$ was the $7 S, 8 R$-configuration. On the other hand, we found that the aromatic quadrant rule for the ${ }^{1} \mathrm{~L}_{\mathrm{a}}$ transition $(220-240 \mathrm{~nm})^{46)}$ is validly applicable to the configurational assignment of a chiral benzylic C-8 position upon examining the neolignans reported in the literature. ${ }^{45)}$ The $8 R$-configuration in $\mathbf{3}$ was thus supported by the negative Cotton effect $\left([\theta]_{229}-1550\right)$ for the ${ }^{1} \mathrm{~L}_{\mathrm{a}}$ transition (Fig. 3). Compound $\mathbf{3}$ was previously reported from Sambucus nigra without assigning the absolute configurations at $\mathrm{C}$ 7 and C-8. ${ }^{47)}$ There are also reports of glycosides of $\mathbf{3}$ from Juniperus communis, ${ }^{48)}$ Pinus silvestris, ${ }^{49)}$ and its enantiomer (cedrusin; $[\alpha]_{\mathrm{D}}+4.39^{\circ}$ ) from Cedrus deodara. ${ }^{50)}$ Accordingly, compound 3 is the first example isolated as the $7 S, 8 R$ form.

Compound 4 was shown to have the molecular formula $\mathrm{C}_{11} \mathrm{H}_{14} \mathrm{O}_{4}$ by the molecular ion peak at $\mathrm{m} / \mathrm{z} 211.0964$ $[\mathrm{M}+\mathrm{H}]^{+}$in HR-FAB-MS. The ${ }^{1} \mathrm{H}-\mathrm{NMR}$ spectrum of $4(\mathrm{Ex}-$ perimental) displayed a monosubstituted benzene signal $\left(\delta_{\mathrm{H}}\right.$ $8.08-7.52)$ and four oxymethylene protons $\left(\delta_{\mathrm{H}} 4.51,3.88\right.$, $3.73,3.67$, each multiplet). In addition to the ${ }^{13} \mathrm{C}-\mathrm{NMR}$ resonances owing to these functionalities, an ester carbonyl carbon was observed at $\delta_{\mathrm{C}} 168.1$ (Experimental). The HMBC correlations (Fig. 2) indicated that compound 4 was a benzoyl ester with a diethylene glycol group. This is also the first isolation from a natural source, although it was previously reported as a synthetic compound. ${ }^{51)}$

\section{Experimental}

General Optical rotations were measured with a Jasco DIP-4 digital polarimeter. The UV spectra were obtained with a Hitachi U-2000 spectrophotometer, and the CD spectra were run on a Jasco J-720 W spectrometer. The ${ }^{1} \mathrm{H}$ - and ${ }^{13} \mathrm{C}$-NMR data (including HSQC, HMBC, NOESY, and ${ }^{1} \mathrm{H}-{ }^{1} \mathrm{H}$ COSY) were measured on a Varian Unity Inova AS600NB instrument operating at 600 and $150 \mathrm{MHz}$, respectively. The chemical shifts are given in $\delta$ $(\mathrm{ppm})$ values relative to those of the solvent $\left[\mathrm{CD}_{3} \mathrm{OD}\left(\delta_{\mathrm{H}} 3.35 ; \delta_{\mathrm{C}} 49.0\right)\right.$, $\left.\mathrm{C}_{5} \mathrm{D}_{5} \mathrm{~N}\left(\delta_{\mathrm{H}} 7.20 ; \delta_{\mathrm{C}} 123.5\right)\right]$ and tetramethylsilane (TMS). The HR-ESI-MS and ESI-MS were obtained on a Micromass AutoSpec OA-Tof spectrometer (solvent: $50 \% \mathrm{MeOH}$ containing $0.1 \% \mathrm{AcONH}_{4}$; flow rate: $0.02 \mathrm{ml} / \mathrm{min}$ ), and FAB-MS using 3-nitrobenzyl alcohol as the matrix agent, including high-resolution mass spectra, were performed on a Micromass AutoSpec OA-Tof spectrometer. Normal phase HPLC was conducted on a YMC-Pack SIL A-003 column $(4.6 \mathrm{~mm}$ i.d. $\times 250 \mathrm{~mm}$; YMC Co., Ltd.) and was developed at room temperature with $n$-hexane/EtOH/formic acid $(75: 24: 1)$ as the solvent (flow rate: $1.5 \mathrm{ml} / \mathrm{min}$; detection: UV $254 \mathrm{~nm}$ ). Reversed-phase HPLC was carried out on a YMC-Pack ODS A-302 column $(4.6 \mathrm{~mm}$ i.d. $\times 150 \mathrm{~mm}$; YMC Co., Ltd.) and was developed at $40{ }^{\circ} \mathrm{C}$ with $10 \mathrm{~mm}$ $\mathrm{H}_{3} \mathrm{PO}_{4} / 10 \mathrm{~mm} \mathrm{KH} \mathrm{PO}_{4} / \mathrm{MeCN}$ ( $4: 4: 2$, flow rate: $\left.1.0 \mathrm{ml} / \mathrm{min}\right)$. Column chromatography was performed with Toyopearl HW-40 (coarse grade; Tosoh Co.), YMC GEL ODS AQ 120-50S (YMC Co., Ltd.), MCI GEL CHP-20P (Mitsubishi Kasei Co.), and Sephadex LH-20 (Pharmacia Fine Chemicals Co., Ltd.). Thin-layer chromatography (TLC) was performed on Kieselgel $60 \mathrm{~F}_{254}$ plates $(0.2 \mathrm{~mm}$ layer thickness, Merck), and the spots were detected by ultraviolet irradiation $(254,366 \mathrm{~nm})$ and by spraying with $10 \% \mathrm{H}_{2} \mathrm{SO}_{4}$ reagent.

Plant Material Chips of S. album L. wood collected in Mysore district of India were used. The wood was officially imported from India under a special treaty between India and Japanese governments to sculpture a Buddhist image in a Japanese temple with a long and distinguished history.

Extraction and Isolation The heartwood of Santalum album $(1.53 \mathrm{~kg})$ was extracted with $\mathrm{MeOH}$ at room temperature. The combined crude $\mathrm{MeOH}$ extract $(73.1 \mathrm{~g})$ was suspended in $20 \% \mathrm{MeOH}(21)$ and then partitioned with $n$-hexane $(3 \times 21)$ and EtOAc $(3 \times 21)$, to afford dried $n$-hexane- $(16.4 \mathrm{~g})$, EtOAc- $(27.1 \mathrm{~g})$, and $\mathrm{H}_{2} \mathrm{O}$-soluble $(17.5 \mathrm{~g})$ residues. The fractionation was achieved by monitoring the eluate using normal- and reversed-phase HPLC. Part $(7.0 \mathrm{~g})$ of the EtOAc extract was chromatographed over a Toyopearl HW-40 column (coarse grade; $2.2 \mathrm{~cm}$ i.d. $\times 65 \mathrm{~cm}$ ) with $\mathrm{H}_{2} \mathrm{O}$ containing increasing amounts of $\mathrm{MeOH}$ in a stepwise gradient mode. The $40 \% \mathrm{MeOH}$ eluate was subjected to column chromatography over a YMC GEL ODS AQ $120-50 \mathrm{~S}$ column $(1.1 \mathrm{~cm}$ i.d. $\times 41 \mathrm{~cm})$ with aqueous $\mathrm{MeOH}$, to yield vanillic acid $4-O$-neohesperidoside $(3.6 \mathrm{mg})$. The $50 \% \mathrm{MeOH}$ eluate was submitted to a combination of chromatography over Sephadex LH-20 $(1.1 \mathrm{~cm}$ i.d. $\times 43 \mathrm{~cm}$ ) (with EtOH), YMC GEL ODS AQ 120-50S $(1.1 \mathrm{~cm}$ i.d. $\times$ $41 \mathrm{~cm}$ ) (with aqueous $\mathrm{MeOH}$ ), and preparative HPLC (YMC-Pack ODS A$302,4.6 \mathrm{~mm}$ i.d. $\times 150 \mathrm{~mm}$ ) with $20 \%$ aqueous $\mathrm{MeCN}$ to yield vanillic acid $(0.8 \mathrm{mg})$, isovanillic acid $(1.0 \mathrm{mg})$, syringic acid $(1.8 \mathrm{mg})$, compound 4 $\left(12.6 \mathrm{mg}, t_{\mathrm{R}} 12.8 \mathrm{~min}\right), 7,8$-erythro-4,9,9'-trihydroxy-3,3'-dimethoxy-8.O.4' neolignan $5 \quad\left(0.9 \mathrm{mg}, t_{\mathrm{R}} 8.7 \mathrm{~min}\right), \quad 7,8$-threo-4,9,9'-trihydroxy-3,3'-dimethoxy-8.O.4' -neolignan $6\left(4.8 \mathrm{mg}, t_{\mathrm{R}} 7.9 \mathrm{~min}\right), \omega$-hydroxypropioguaiacone (3.2 mg, $\left.t_{\mathrm{R}} 3.4 \mathrm{~min}\right), 3$-hydroxy-1-(4-hydroxy-3,5-dimethoxyphenyl)-1propanone $\left(5.0 \mathrm{mg}, t_{\mathrm{R}} 4.9 \mathrm{~min}\right)$, and $C$-veratroylglycol $\left(1.9 \mathrm{mg}, t_{\mathrm{R}} 5.2 \mathrm{~min}\right)$. Similarly, the $60 \% \mathrm{MeOH}$ eluate was chromatographed over Sephadex LH$20(1.1 \mathrm{~cm}$ i.d. $\times 43 \mathrm{~cm})$ and YMC GEL ODS AQ 120-50S $(1.1 \mathrm{~cm}$ i.d. $\times 41 \mathrm{~cm}$ ), followed by preparative HPLC (YMC-Pack ODS A-302, $4.6 \mathrm{~mm}$ i.d. $\times 150 \mathrm{~mm}$ ) using $20 \%$ aqueous $\mathrm{MeCN}$ to afford pure compounds $1\left(12.9 \mathrm{mg}, t_{\mathrm{R}} 9.8 \mathrm{~min}\right), 2\left(3.7 \mathrm{mg}, t_{\mathrm{R}} 17.4 \mathrm{~min}\right)$, and $\mathbf{3}\left(2.7 \mathrm{mg}, t_{\mathrm{R}} 5.8 \mathrm{~min}\right)$; dihydrodehydrodiconiferyl alcohol (7) $\left(4.7 \mathrm{mg}, t_{\mathrm{R}} 15.4 \mathrm{~min}\right)$; $(7 S, 8 S)-3-$ methoxy-3',7-epoxy-8,4'-oxyneoligna-4,9,9'-triol (8) (8.2 mg, $\left.t_{\mathrm{R}} 20.4 \mathrm{~min}\right)$; $\left(7^{\prime} S, 8 R, 8^{\prime} R\right.$ )-lynoniresinol (9) (10.4 mg, $\left.t_{\mathrm{R}} 5.4 \mathrm{~min}\right)$; 2,3-bis[(4-hydroxy-3,5dimethoxyphenyl)-methyl]-1,4-butanediol (10) $\left(1.3 \mathrm{mg}, t_{\mathrm{R}} 6.0 \mathrm{~min}\right)$; and $(-)$-secoisolariciresinol (11) $\left(7.0 \mathrm{mg}, t_{\mathrm{R}} 12.84 \mathrm{~min}\right)$. The eluate with $70 \%$ $\mathrm{MeOH}$ from the Toyopearl HW-40 $(2.2 \mathrm{~cm}$ i.d. $\times 65 \mathrm{~cm})$ was further fractionated by column chromatography on Sephadex LH-20 $(1.1 \mathrm{~cm}$ i.d. $\times 43 \mathrm{~cm})$ and YMC GEL ODS AQ 120-50S $(1.1 \mathrm{~cm}$ i.d. $\times 41 \mathrm{~cm})$ with aqueous $\mathrm{MeOH}$ to afford a mixture of compounds $1,2,7$, and $\mathbf{8}$, each of which was finally purified by preparative HPLC (YMC-Pack SIL A-003, $4.6 \mathrm{~mm}$ i.d. $\times 250 \mathrm{~mm})$ developed with $n$-hexane/EtOH $(75: 25)$, to yield additional quantities of compounds $\mathbf{1}(5.8 \mathrm{mg}), \mathbf{2}(2.7 \mathrm{mg}), \mathbf{7}(10.7 \mathrm{mg})$, and $\mathbf{8}$ (19.1 mg).

Compound (1): Colorless oil, $[\alpha]_{\mathrm{D}}^{20}+8.0^{\circ}(c=1.0, \mathrm{MeOH})$. UV $\lambda_{\max }$ $\mathrm{MeOH} n m(\log \varepsilon): 223(2.43), 273$ (2.00). CD (MeOH; $[\theta]) \mathrm{nm} 224$ $(-2437), 237(+2480), 282(+2549)$. FAB-MS $m / z 391[\mathrm{M}+\mathrm{H}]^{+}$. HRFAB-MS $m / z 391.1379[\mathrm{M}+\mathrm{H}]^{+}$(Calcd for $\mathrm{C}_{20} \mathrm{H}_{22} \mathrm{O}_{8}+\mathrm{H}, 391.1392$ ). ${ }^{1} \mathrm{H}-$ and ${ }^{13} \mathrm{C}-\mathrm{NMR}$ data: Table 1 .

$7 S, 8 S$-Nitidanin (2): Colorless oil, $[\alpha]_{\mathrm{D}}^{20}-16.0^{\circ}(c=0.5, \mathrm{MeOH})$. UV

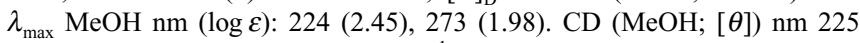
$(-1312), 236(+1646), 288(+1684) .{ }^{1} \mathrm{H}-\mathrm{NMR}\left(\mathrm{CD}_{3} \mathrm{OD}\right): \delta 6.78(2 \mathrm{H}, \mathrm{s}, \mathrm{H}-$ 2, 6), $6.74\left(1 \mathrm{H}, \mathrm{d}, J=1.8 \mathrm{~Hz}, \mathrm{H}-2^{\prime}\right), 6.69\left(1 \mathrm{H}, \mathrm{d}, J=1.8 \mathrm{~Hz}, \mathrm{H}-6^{\prime}\right), 6.53(1 \mathrm{H}$, br d, $\left.J=15.6 \mathrm{~Hz}, \mathrm{H}^{\prime} 7^{\prime}\right), 6.28\left(1 \mathrm{H}, \mathrm{dt}, J=15.6,5.4 \mathrm{~Hz}, \mathrm{H}-8^{\prime}\right), 4.93(1 \mathrm{H}, \mathrm{d}$, $J=8.4 \mathrm{~Hz}, \mathrm{H}-7), 4.24\left(2 \mathrm{H}, \mathrm{dd}, J=5.4,1.8 \mathrm{~Hz}, \mathrm{H}-9^{\prime}\right), 4.08(1 \mathrm{H}, \mathrm{ddd}, J=8.4$, $4.8,3.0 \mathrm{~Hz}, \mathrm{H}-8), 3.93\left(3 \mathrm{H}, \mathrm{s}, \mathrm{MeO}-3^{\prime}\right), 3.90(6 \mathrm{H}, \mathrm{s}, \mathrm{MeO}-3,5), 3.77(1 \mathrm{H}$, dd, $J=12.6,3.0 \mathrm{~Hz}, \mathrm{H}-9), 3.55(1 \mathrm{H}$, dd, $J=12.6,4.8 \mathrm{~Hz}, \mathrm{H}-9) ;{ }^{13} \mathrm{C}-\mathrm{NMR}$ $\left(\mathrm{CD}_{3} \mathrm{OD}\right) \delta 147.5(\mathrm{C}-1), 146.7(\mathrm{C}-3,5), 143.1\left(\mathrm{C}-5^{\prime}\right), 134.6(\mathrm{C}-4), 131.6(\mathrm{C}-$ 4'), $128.9\left(\mathrm{C}-8^{\prime}\right), 128.8$ (C-1), $128.4\left(\mathrm{C}-1^{\prime}\right), 125.9$ (C-7'), $106.5\left(\mathrm{C}-6^{\prime}\right)$, $103.3(\mathrm{C}-2,6), 101.3\left(\mathrm{C}-2^{\prime}\right), 77.4(\mathrm{C}-8), 75.2(\mathrm{C}-7), 61.0\left(\mathrm{C}-9^{\prime}\right), 59.4(\mathrm{C}-9)$, $54.1(\mathrm{C}-3,5 \mathrm{MeO}), 54.0\left(\mathrm{C}-3^{\prime} \mathrm{MeO}\right)$. ESI-MS $m / z 422\left[\mathrm{M}+\mathrm{NH}_{4}\right]^{+}$. HRESI-MS $m / z 422.1827\left[\mathrm{M}+\mathrm{NH}_{4}\right]^{+}$(Calcd for $\mathrm{C}_{21} \mathrm{H}_{24} \mathrm{O}_{8}+\mathrm{NH}_{4}, 422.1815$ ).

Hydrogenation of 1 and 2 To solution of $\mathbf{1}(6.0 \mathrm{mg})$ [or $2(2.0 \mathrm{mg})$ ] in EtOH were added $\mathrm{PtO}_{2}(\mathbf{1}, 6.0 \mathrm{mg} ; 2,2.0 \mathrm{mg})$. A mixture was subjected to catalytic hydrogenation for $2 \mathrm{~h}$ with stirring under monitoring the reaction 
process by reversed-phase HPLC ( $20 \%$ aqueous $\mathrm{MeCN})$. The reaction mixture was filtered and concentrated to give the pure dihydro-derivatives, 1a $\left(t_{\mathrm{R}}\right.$ $10.2 \mathrm{~min} ; 5.9 \mathrm{mg})$ and $\mathbf{2 b}\left(t_{\mathrm{R}} 18.5 \mathrm{~min} ; 1.8 \mathrm{mg}\right)$.

1a: Colorless oil, $[\alpha]_{\mathrm{D}}^{20}-6.3^{\circ}(c=1.0, \mathrm{MeOH}) ; \mathrm{UV} \lambda_{\max } \mathrm{MeOH} \mathrm{nm}$

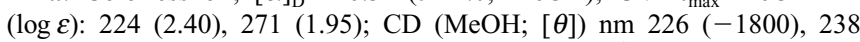
(+4806), 299 (-1010); FAB-MS $m / z 393[\mathrm{M}+\mathrm{H}]^{+} .{ }^{1} \mathrm{H}-\mathrm{NMR}\left(\mathrm{CD}_{3} \mathrm{OD}\right) \delta$ $6.62\left(1 \mathrm{H}, \mathrm{d}, J=1.8 \mathrm{~Hz}, \mathrm{H}-2^{\prime}\right), 6.59\left(1 \mathrm{H}, \mathrm{d}, J=1.8 \mathrm{~Hz}, \mathrm{H}-6^{\prime}\right), 6.51(1 \mathrm{H}, \mathrm{d}$, $J=1.8 \mathrm{~Hz}, \mathrm{H}-2), 6.41(1 \mathrm{H}, \mathrm{d}, J=1.8 \mathrm{~Hz}, \mathrm{H}-6), 4.82(1 \mathrm{H}, \mathrm{d}, J=7.8 \mathrm{~Hz}, \mathrm{H}-7)$, 3.99 (1H, ddd, $J=7.8,4.8,2.4 \mathrm{~Hz}, \mathrm{H}-8), 3.90\left(3 \mathrm{H}, \mathrm{s}, \mathrm{MeO}-3^{\prime}\right), 3.89(3 \mathrm{H}, \mathrm{s}$, MeO-3), 3.74 (1H, dd, $J=12.6,2.4 \mathrm{~Hz}, \mathrm{H}-9), 3.60$ (2H, t, $\left.J=6.0 \mathrm{~Hz}, \mathrm{H}-9^{\prime}\right)$, $3.57(1 \mathrm{H}, \mathrm{dd}, J=12.6,4.8 \mathrm{~Hz}, \mathrm{H}-9), 2.62\left(2 \mathrm{H}\right.$, brt, $\left.J=7.8 \mathrm{~Hz}, \mathrm{H}-7^{\prime}\right), 1.85$ (2H, m, H-8').

2a: Colorless oil, $[\alpha]_{\mathrm{D}}^{20}-9.3^{\circ}(c=0.5, \mathrm{MeOH}) ; \mathrm{UV} \lambda_{\max } \mathrm{MeOH} \mathrm{nm}$

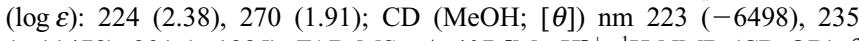
$(+11478), 291(-1885) ;$ FAB-MS $m / z 407[\mathrm{M}+\mathrm{H}]^{+} .{ }^{1} \mathrm{H}-\mathrm{NMR}\left(\mathrm{CD}_{3} \mathrm{OD}\right) \delta$ $6.76\left(2 \mathrm{H}, \mathrm{s}, \mathrm{H}-2^{\prime}, 6^{\prime}\right), 6.52\left(1 \mathrm{H}, \mathrm{d}, J=1.8 \mathrm{~Hz}, \mathrm{H}-2^{\prime}\right), 6.47(1 \mathrm{H}, \mathrm{d}, J=1.8 \mathrm{~Hz}$, H-6' $), 4.93$ (1H, d, $J=7.8 \mathrm{~Hz}, \mathrm{H}-7), 4.04$ (1H, ddd, $J=7.8,4.8,2.4 \mathrm{~Hz}, \mathrm{H}-8)$, $3.90(6 \mathrm{H}, \mathrm{s}, \mathrm{MeO}-3), 3.89\left(3 \mathrm{H}, \mathrm{s}, \mathrm{MeO}-3^{\prime}\right), 3.75(1 \mathrm{H}$, dd, $J=12.6,2.4 \mathrm{~Hz}$, H-9), $3.60\left(2 \mathrm{H}, \mathrm{t}, J=6.6 \mathrm{~Hz}, \mathrm{H}-9^{\prime}\right), 3.54(1 \mathrm{H}, \mathrm{dd}, J=12.6,4.8 \mathrm{~Hz}, \mathrm{H}-9), 2.63$ $\left(2 \mathrm{H}\right.$, br t, $\left.J=7.8 \mathrm{~Hz}, \mathrm{H}-7^{\prime}\right), 1.85$ ( $\left.2 \mathrm{H}, \mathrm{m}, \mathrm{H}-8^{\prime}\right)$.

(7S,8R)-Dihydro-3' -hydroxy-8-hydroxy-methyl-7-(4-hydroxy-3-methoxyphenyl)-1'-benzofuranpropanol (3): Yellowish oil, $[\alpha]_{\mathrm{D}}^{20}-5.3^{\circ} \quad(c=1.0$, $\mathrm{MeOH})$. UV $\lambda_{\max } \mathrm{MeOH} \mathrm{nm}(\log \varepsilon): 212$ (3.10), 257 (1.58), 282 (1.97). CD $(\mathrm{MeOH} ;[\theta]) \mathrm{nm} 229(-1550), 295(+643) .{ }^{1} \mathrm{H}-\mathrm{NMR}\left(\mathrm{CD}_{3} \mathrm{OD}\right): \delta 7.02$ $(1 \mathrm{H}, \mathrm{d}, J=2.4 \mathrm{~Hz}, \mathrm{H}-2), 6.89(1 \mathrm{H}, \mathrm{dd}, J=8.4,2.4 \mathrm{~Hz}, \mathrm{H}-6), 6.80(1 \mathrm{H}, \mathrm{d}$, $J=8.4 \mathrm{~Hz}, \mathrm{H}-5), 6.65(1 \mathrm{H}$, br s, H-2' $), 6.61\left(1 \mathrm{H}\right.$, br d, $\left.J=1.8 \mathrm{~Hz}, \mathrm{H}-6^{\prime}\right), 5.53$ $(1 \mathrm{H}, \mathrm{d}, J=6.0 \mathrm{~Hz}, \mathrm{H}-7), 3.87(1 \mathrm{H}, \mathrm{m}, \mathrm{H}-9), 3.86(3 \mathrm{H}, \mathrm{s}, \mathrm{MeO}-3), 3.79(1 \mathrm{H}$, dd, $J=10.8,7.2 \mathrm{~Hz}, \mathrm{H}-9), 3.60\left(2 \mathrm{H}, \mathrm{t}, J=6.0 \mathrm{~Hz}, \mathrm{H}-9^{\prime}\right), 3.49$ (1H, dd, $J=12.6,6.0 \mathrm{~Hz}, \mathrm{H}-8), 2.60\left(2 \mathrm{H}\right.$, br t, $\left.J=7.2 \mathrm{~Hz}, \mathrm{H}-7^{\prime}\right), 1.83\left(2 \mathrm{H}, \mathrm{m}, \mathrm{H}-8^{\prime}\right)$. ${ }^{13} \mathrm{C}-\mathrm{NMR}\left(\mathrm{CD}_{3} \mathrm{OD}\right) \delta 149.1(\mathrm{C}-3), 147.4(\mathrm{C}-4), 146.5\left(\mathrm{C}-4^{\prime}\right), 141.9\left(\mathrm{C}-3^{\prime}\right)$, $136.7\left(\mathrm{C}-1^{\prime}\right), 135.1\left(\mathrm{C}-5^{\prime}\right), 129.8$ (C-1), 119.7 (C-6), $117.0\left(\mathrm{C}-6^{\prime}\right), 116.7$ (C$\left.2^{\prime}\right), 116.1$ (C-5), 110.5 (C-2), 88.7 (C-7), 65.2 (C-9), 62.3 (C-9'), 56.4 (C-3 $\mathrm{MeO}), 55.8(\mathrm{C}-8), 35.8\left(\mathrm{C}-8^{\prime}\right), 32.7\left(\mathrm{C}-7^{\prime}\right)$. ESI-MS $m / z 364\left[\mathrm{M}+\mathrm{NH}_{4}\right]^{+}$. HR-ESI-MS $m / z \quad 364.1778 \quad\left[\mathrm{M}+\mathrm{NH}_{4}\right]^{+} \quad\left(\right.$ Calcd for $\mathrm{C}_{19} \mathrm{H}_{22} \mathrm{O}_{6}+\mathrm{NH}_{4}$, 364.1760).

Diethylene Glycol Monobenzoate (4): Colorless oil, UV $\lambda_{\max } \mathrm{MeOH} n m$ $(\log \varepsilon): 210$ (1.60), 228 (2.30). ${ }^{1} \mathrm{H}-\mathrm{NMR}\left(\mathrm{CD}_{3} \mathrm{OD}\right): \delta 8.08(2 \mathrm{H}, \mathrm{m}, \mathrm{H}-2,6)$, $7.65(1 \mathrm{H}, \mathrm{m}, \mathrm{H}-4), 7.52$ (2H, m, H-3, 5), $4.51(2 \mathrm{H}, \mathrm{m}, \mathrm{H}-8), 3.88(2 \mathrm{H}, \mathrm{m}, \mathrm{H}-$ 9), 3.73 (2H, m, H-11), 3.67 (2H, m, H-10). ${ }^{13} \mathrm{C}-\mathrm{NMR}\left(\mathrm{CD}_{3} \mathrm{OD}\right): \delta 168.1$ (C-7), 134.3 (C-4), 131.4 (C-1), 130.6 (C-2, 6), 129.6 (C-3, 5), 73.8 (C-10), 70.2 (C-9), 65.4 (C-8), 62.2 (C-11). FAB-MS $m / z 211[\mathrm{M}+\mathrm{H}]^{+}$. HR-FABMS $m / z 211.0964[\mathrm{M}+\mathrm{H}]^{+}\left(\right.$Calcd for $\left.\mathrm{C}_{11} \mathrm{H}_{14} \mathrm{O}_{4}+\mathrm{H}, 211.0970\right)$.

Acknowledgements The authors thank Kannonshoji temple in Shiga prefecture for kind donation of sandalwood chips used for the research. We also thank the SC NMR Laboratory of Okayama University for performing the NMR spectroscopy. One of the authors (T.H.K.) acknowledges the Ministry of Education, Culture, Sports, Science and Technology of Japan for a scholarship.

\section{References and Notes}

1) Kapoor L. D., "Handbook of Ayurvedic Medicinal Plants," CRC Press, Boca, Raton, FL, 1990.

2) Benencia F., Courreges M. C., Phytomedicine, 6, 119-123 (1999).

3) Banerjee S., Ecavade A., Rao A. R., Cancer Lett., 68, 105-109 (1993).

4) Dwivedi C., Abu-Ghazaleh A., Eur. J. Cancer Prev., 6, 399-401 (1997).

5) Dwivedi C., Zang Y., Eur. J. Cancer Prev., 8, $449-455$ (1999).

6) Shankaranarayana K. H., Ayyar K. S., Krishna Rao G. S., Phytochemistry, 19, 1239-1240 (1980).

7) Shankaranarayana K. H., Ayyar K. S., Krishna Rao G. S., Current Sci., 49, 198-199 (1980).

8) Gibbard S., Schoental R., J. Chromatogr., 44, 396-398 (1969).

9) Adams D. R., Bhatnagar S. P., Cooksoon R. C., Phytochemistry, 14, 1459-1460 (1975).

10) Demole E., Demole C., Enggist P., Helv. Chim. Acta, 59, 737-747 (1976).

11) Christenson P. A., Secord N., Willis B. J., Phytochemistry, 20, 11391141 (1981).

12) Ranibai P., Ghatge B. B., Patil B. B., Bhattacharyya S. C., Indian J. Chem., 25B, 1006-1013 (1986).

13) Corey E. J., Kirst H. A., Katzenellenbogen J. A., J. Am. Chem. Soc., 92, 6314-6319 (1970).
14) Solas D., Wolinsky J., J. Org. Chem., 48, 1988-1991 (1983).

15) Kaur M., Agarwal C., Singh R. P., Guan X., Dwivedi C., Agarwal R., Carcinogenesis, 26, 369-380 (2005).

16) Okugawa H., Ueda R., Matsumoto K., Kawanishi K., Kato A., Phytomedicine, 2, 119-126 (1995).

17) Okugawa H., Ueda R., Matsumoto K., Kawanishi K., Kato K., Phytomedicine, 7, 417-422(2000).

18) Dwivedi C., Guan X., Harmsen W. L., Voss A. L., Goetz-Parten D. E., Koopman E. M., Johnson K. M., Valluri H. B., Matthees D. P., Cancer Epidemiology, Biomarkers \& Prevention, 12, 151-156 (2003).

19) Hongratanaworakit T., Heuberger E., Buchbauer G., Planta Med., 70, 3-7 (2004).

20) Matsushita H., Miyase T., Ueno A., Phytochemistry, 30, 2025-2027 (1991).

21) Fukuyama Y., Nakahara M., Minami H., Kodama M., Chem. Pharm. Bull., 44, 1418-1420 (1996).

22) Fang J.-M., Lee C.-K., Cheng Y.-S., Phytochemistry, 31, 3659-3661 (1992).

23) Dada G., Corbani A., Manitto P., Speranza G., J. Nat. Prod., 52, 1327-1330 (1989).

24) Perez C., Almonacid L. N., Trujillo J. M., Conzalez A. G., Alonso S. J., Navarro E., Phytochemistry, 40, 1511-1513 (1995).

25) Agrawal P. K., Rastogi R. P., Phytochemistry, 21, 1459-1461 (1982).

26) Achenbach H., Stocker M., Constenila M., A, Phytochemistry, 27, 1835-1841 (1988).

27) Nakasone Y., Takara K., Wada K., Tanaka J., Yogi S., Nakatani N., Biosci. Biotech. Biochem., 60, 1714-1716 (1996).

28) Kijjoa A., Pinto M. M. M., Anantachoke C., Gedris T. E., Herz W., Phytochemistry, 40, 191-193 (1995).

29) Kraut L., Mues R., Z. Naturforsch., 54c, 6-10 (1999).

30) Ishikawa T., Seki M., Nishigaya K., Miura Y., Seki H., Chen I.-S., Ishii H., Chem. Pharm. Bull., 43, 2014-2018 (1995).

31) Takahasi H., Yanagi K., Ueda M., Nakade K., Fukuyama Y., Chem. Pharm. Bull., 51, 1377-1381 (2003).

32) Waibel R., Benirschke G., Benirschke M., Achenbach H., Phytochemistry, 62, 805-811 (2003).

33) Afifi M. S. A., Ahmed M. M., Pezzuto J. M., Kinghorn A. D., Phytochemistry, 34, 839-841 (1993).

34) Kumar S., Ray A. B., Konno C., Oshima Y., Hikino H., Phytochemistry, 27, 636-638 (1988).

35) Lee D., Cuendet M., Vigo J. S., Graham J. G., Cabieses F., Fong H. H. S., Pezzuto J. M., Kinghorn A. D., Org. Lett., 3, 2169-2171 (2001).

36) Arnoldi A., Merlini L., J. Chem. Soc. Perkin Trans. I, 1985, 25552557 (1985).

37) Agrawal P. K., Rastogi R. P., Osterdahl B.-G., Org. Magn. Res., 1983, 119-121 (1983).

38) Li S., Iliefski T., Lundquist K., Wallis A. F. A., Phytochemistry, 46, 929-934 (1997).

39) Yuen M. S. M., Xue F., Mak T. C. W., Wong H. N. C., Tetrahedron, 54, 12429-12444 (1998).

40) Yoshikawa K., Kinoshita H., Kan Y., Arihara S., Chem. Pharm. Bull., 43, 578-581 (1995).

41) Lemiere G., Gao M., De Goot A., Dommisse R., Lepoivre J., Pieters L., Buss V., J. Chem. Soc. Perkin Trans. 1, 1995, 1775-1779 (1995).

42) Nascimento I. R., Lopes L. M. X., Davin L. B., Lewis N. G., Tetrahedron, 56, 9181-9193 (2000).

43) Miyase T., Ueno A., Takizawa N., Konbayashi H., Oguchi H., Phytochemistry, 28, 3483-3485 (1989).

44) Achenbach H., Grob J., Dominguez X. A., Cano G., Star J. V., Brussolo L. D. C., Munoz G., Salgado F., Lopez L., Phytochemistry, 26, 1159-1166 (1987).

45) Antus S., Kurtan T., Juhasz L., Kiss L., Hollosi M., Majer Z., Chirality, 13, 493-506 (2001).

46) DeAngelis G. G., Wildman W. C., Tetrahedron, 25, 5099-5112 (1969).

47) D’Abrosca B., Dellagreca M., Fiorentino A., Monaco P., Previtera L., Simonet A. M., Zarrelli A., Phytochemistry, 58, 1073-1081 (2001).

48) Nakanishi T., Iida N., Inatomi Y., Murata H., Inada A., Murata J., Lang F. A., Iinuma M., Tanaka T., Phytochemistry, 65, 207-213 (2004).

49) Popoff T., Theander O., Phytochemistry, 14, 2065-2066 (1975).

50) Agrawal P. K., Agrawal S. K., Rastogi R. P., Phytochemistry, 19, $1260-1261$ (1980).

51) Gopinath R., Barkakaty B., Talukdar B., Patel B. K., J. Org. Chem., 68, $2944-2947$ (2003). 